\title{
FAKE IMPERFECTIVE IMPERATIVES IN SLAVIC
}

\author{
SILJE SUSANNE ALVESTAD \\ University of Oslo
}

\section{A B S T R ACT}

The starting point of this article is a comparative corpus-based study of how verbal aspect is used in the imperative in 12 different Slavic languages namely, Russian (Ru), Belarusian (By), Ukrainian (Uk), Bulgarian (Bg), Polish (Pl), Serbian (Sr), Croatian (Hr), Macedonian (Mk), Upper Sorbian (US), Slovak (Sk), Czech ( $\mathrm{Cz}$ ), and Slovene (Sn). The findings corroborate the results of previous studies of aspect use in the indicative (Dickey (2000), for example), as well as recent studies of aspect use in the imperative by Benacchio (2010) and von Waldenfels (2012): the imperfective aspect (IPF) is significantly more widespread in the East Slavic languages - $\mathrm{Ru}, \mathrm{By}$, and $\mathrm{Uk}$ - than in the West Slavic ones - Cz, Sk, and Sn, while Bg, Pl, Sr, Hr, Mk, and US make up a middle continuum of languages stretching from more to less IPF-oriented. However, contrary to Dickey (2000), who takes the meanings of the aspects to vary across the Slavic languages, the author of this article takes the meaning of the perfective (PF) aspect to be the same in all the Slavic languages.

The question addressed in the article is why, in particularly the East Slavic languages, IPF is so widespread. It is shown that in many of the cases in question, IPF refers to a single, complete event. It is argued that what we see in these cases is simply the same phenomenon that is referred to as the general-factual IPF when it occurs in the indicative, with the exception that the presuppositional type of the general-factual IPF in the imperative typically involves identification at the level of event type, not token, as in the indicative. Since imperatives are not about facts, the general-factual IPF is instead referred to as the fake IPF.

On this analysis, what some researchers consider to be aspectual meanings specific to the imperative come out neatly as epiphenomena of aspect use.

\section{[1] INTRODUCTION}

In comparative Slavic aspectology imperatives have, just until recently, been largely ignored. In Russian aspectology imperatives have, to some extent, been taken into consideration, but puzzles still remain. A case in point is (1) below. Specifically, given that we typically use imperatives when we want the addressee to change the world in some way, we would expect the aspect most widely used to be the perfective (PF). However, the results of my own comparative corpus study, 
which are supported by Benacchio (2010) and von Waldenfels (2012), show that this expectation is borne out only for a minority of the Slavic languages, as illustrated in (1). ${ }^{12}$

(1) a. Ru: Я знаю, почему он не стонал и вообще не стонет. На мой вопрос он ответил: - “Читайте ІРғ роман “Овод”, тогда узнаете."

(ParaSol. Ostrovskij: Kak zakaljalas' stal')

I know now why he never groans. I asked him, and he replied: "Read the novel "The Gadfly" and you'll know."

b. Вy: - “Чытайце Іірғ раман "Авадзень”, тады будзеце ведаць."

c. Uk: - “Читайте IPF роман “Овід”, тоді знатимете.”

d. Bg: - “Четете

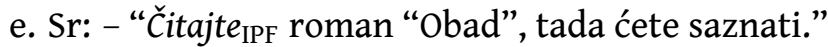

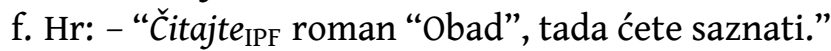

g. US: - "Čitajće ${ }_{\mathrm{IPF}}$ roman "Spinadło" a budźeće wědźeć!"

h. Sn: - "Berite $\mathrm{IPF}$ roman "Obad", pa boste vedeli."

i. Pl: - "Przeczytajcie ${ }_{\mathrm{PF}}$ powieść "Szerszeń", to się dowiecie."

j. Mk: - "Прочитајтерғ го романот "Штркел”, тогаш ќе разберете."

k. Sk: - "Prečítajte $e_{\mathrm{PF}}$ si román "Ovad", dozviete sa."

1. Cz: - "Přečtěte $e_{\mathrm{PF}}$ si román "Střeček" a dovíte se to!"

As we can see, $\mathrm{PF}$ is used in only $\mathrm{Pl}, \mathrm{Mk}$, Sk and $\mathrm{Cz}$. The other Slavic languages under consideration, $\mathrm{Ru}, \mathrm{By}, \mathrm{Uk}, \mathrm{Bg}, \mathrm{Sr}, \mathrm{Hr}$, US and $\mathrm{Sn}$, use the imperfective aspect (IPF), despite the fact that the verb phrase (VP) describes a single, complete event.

The question I will address in this paper is this: In particularly the East-Slavic languages, why is IPF so widespread? In the existing literature, the prevalent view is that the semantics of the aspects is different in the imperative than in the indicative. Three proposals are made. First, Padučeva $(1996,68,70)$, among others, argues that in the imperative, IPF in Russian focuses on the initial phase of the event and includes the semantic component nemedlenno 'immediately'. Second, Lehmann $(1989,78)$ argues that, "[i]n the context of the imperative each aspect correlates with a different set of speech acts", where IPF is typically associated with permissions. Finally, Benacchio $(2010,13)$ argues that in the imperative, the aspects take on "completely different, secondary meanings (...) associated with the category of politeness". IPF is taken to be used when the speaker wants to be particularly polite or particularly rude. None of these proposals can explain the

[1] For the languages under consideration I will use the following abbreviations: $\mathrm{Ru}=\mathrm{Russian}, \mathrm{By}=$ Belarusian, $\mathrm{Uk}=$ Ukrainian, $\mathrm{Bg}=\mathrm{Bulgarian}, \mathrm{Pl}=\mathrm{Polish}, \mathrm{Sr}=\mathrm{Serbian}, \mathrm{Hr}=\mathrm{Croatian}, \mathrm{Mk}=$ Macedonian, $\mathrm{US}=\mathrm{Upper}$ Sorbian, $\mathrm{Sk}=$ Slovak, $\mathrm{Cz}=\mathrm{Czech}$, and $\mathrm{Sn}=$ Slovene.

[2] The example is from the ParaSol corpus, “(...) a parallel aligned corpus of translated and original belletristic texts in Slavic and some other languages" (http://parasol . unibe.ch/) and the English translation is from Prokofeva (1959). 
use of IPF in examples such as (1), however. The interpretation in (1) is neither one of commencement nor of immediacy, and the imperative is neither particularly polite nor particularly rude, and finally, it is not a permission.

I will argue that what we see in examples such as (1) is simply the same phenomenon that is referred to as the general-factual IPF when it occurs in the indicative. It follows that the links drawn between IPF in the imperative and i) focus on the initial phase of the event (Padučeva 1996), ii) speech acts such as permissions (Lehmann 1989), and iii) a particularly high or low degree of politeness (Benacchio 2010) are indirect and must be considered epiphenomena of aspect use.

\section{[2] B ACKGROUND}

In the most comprehensive account to date of aspect use in Slavic languages, (Dickey 2000), seven different types of contexts of aspect use are considered, but one important verb form is not accounted for: the imperative. In 2010, Benacchio's monograph appeared, and in 2012 and 2013 two comparative corpus-based accounts of aspect use in Slavic imperatives emerged - von Waldenfels (2012) and my own dissertation, Alvestad (2013). ${ }^{3}$

In Alvestad (2013) I made use of the ParaSol corpus and, taking Nikolaj Ostrovskij's 1936 novel Kakzakaljalas' stal' (KZS) - How the steel was tempered - as my point of departure, I isolated all non-negated imperatives in the source language - Russian - referring to any one of Vendler's (1957) situation types. This constituted 234 Russian forms in total. I subsequently isolated their non-negated imperative counterparts in the 11 target languages and subjected the data to statistical analysis, and the results are as follows: whereas $\mathrm{Sk}, \mathrm{Cz}$ and $\mathrm{Sn}$ use IPF in just about $30 \%$ of the cases, the percentage for $\mathrm{Ru}$, By and Uk is $60 \%$. The rest of the languages constitute a middle continuum where the percentage of IPF imperatives varies between, roughly, 40 and $50 \%$.

As far as the cross-Slavic divide in aspect use is concerned, Dickey's (2000), Benacchio's (2010), and von Waldenfels' (2012) accounts correspond to my own: IPF is significantly more widespread in the East-Slavic languages - Ru, By and Uk - than in the West-Slavic Sk and Cz, and Sn. Our accounts diverge, however, when it comes to how we analyze these results.

Dickey (2000) argues that the semantics of the aspects in East-Slavic is distinct from the semantics of the aspects in West-Slavic. Although he is not explicit on this point, von Waldenfels (2012) tacitly adopts Dickey's analysis. Benacchio's (2010) analysis is referred to in Section [1].

In my analysis, the meaning of PF is taken to be identical across the Slavic languages while IPF is semantically underspecified. Following Klein (1995), I take the meaning of PF to be the inclusion of the event time in the reference time, $e \subset$

[3] See also Fortuin \& Pluimgraaff (forthcoming), a corpus-based study of aspect use in imperatives in Ru and Sn. 
$t$, and the meaning of IPF to be the temporal overlap between the event time and the reference time, $e \circ t$. It follows from this analysis that the cross-Slavic variation in aspect use is due to the fact that the languages resolve cases of aspectual competition in different ways. ${ }^{4}$

\section{[3] ASPECTUAL COMPETITION AND THE GENERAL-FACTUAL/FAKE IPF}

Aspectual competition arises in contexts where both aspects can be used without changing the meaning significantly. When IPF "wins" this competition, it receives a so-called general-factual interpretation (see, e.g., Padučeva (1996)). In such cases IPF has a perfective meaning: it refers to a single, complete event. In other words, the meaning of the general-factual IPF is $e \subset t$.

Grønn (2004) identifies two types of the general-factual IPF: the existential type and the presuppositional type. When the IPF VP is used to simply assert the existence of a particular event, typically in the past, the interpretation is existential. A classic example from the literature is Ja čitala "Vojnu i mir" 'I have read War and Peace'. The time at which the speaker read the novel, is not important, just the fact that she did. When the IPF VP is used to refer to an event that has already been introduced in the context, the interpretation is presuppositional. An example is IPF pisal 'wrote' in (2).

(2) $\mathrm{Ru}: \mathrm{B}$ этой портерной я написал

Писал IPF карандашом. ${ }^{5}$ (Grønn 2004, 192), from (Forsyth 1970, 86)

In this tavern, I wrote my first love letter to Vera. I wrote [it] in pencil.

Since we are concerned with imperatives and imperatives are not associated with facts, if we find this interpretation in the imperative, then we need a different term. Following Iatridou $(2000,2009)$ on the past tense and subsequently Grønn (2013) on aspect in counterfactuals, I will refer to IPF in such cases as 'fake'. It is devoid of its standard meaning and, hence, without semantic impact.

As mentioned, imperatives are not about facts, and since they are, furthermore, directed towards the future, it is not obvious that the fake IPF occurs in the imperative. My findings, however, suggest that it does. I will argue that we are in fact dealing with the same phenomenon, that is, the phenomenon that is referred to as the general-factual IPF when it occurs in declaratives and interrogatives.

As regards the presuppositional type fake IPF, I set out with the strong hypothesis that event token identification, as seen in (2), occurs in the imperative too. It will become evident, however, that this hypothesis needs to be modified.

[4] Establishing, for each language, the exact rules, pragmatic or other, that govern the use of aspect in such cases is beyond the scope of this paper, however.

[5] 'Pisal' is underlined to show that the event referred to is presupposed. 
[4] THE EXISTENTIAL TYPE FAKE IPF

In (3) below, William and Adso find themselves in a labyrinth. William gives a detailed account of how they can get out and Adso is impressed.
a. Ru: - “Как вы все это помните? Вы изучалирғ лабиринты?” - “Нет. Я вспомнил старинный текст, который однажды читалІРF."
(ParaSol. Eco: Il nome della rosa)
"How do you know all that? Are you an expert on labyrinths?" "No, I am citing an ancient text I once read." 6
b. Uk: - "Нi, я цитую з однієї давньої книги, яку колись читавІPF."
c. Bg: - "Не, цитирам ти един древен текст, който четохІРғ доста отдавна."
d. Pl: - "Nie, recytuję tylko stary tekst, który kiedyś czytałem IPF."
e. Hr: - "Nisam, izgovaram dio starog spisa koji sam jednom čitao IPF."
f. Sk: - "Nie, to len citujem jeden starý text, ktorý som kedysi čítal $\mathrm{IPF}_{\mathrm{IPF}}$ "
g. Sr: - "Не, наводим из једног старог текста који сам некада прочитаорғ."
h. Mk: - "Не, само цитирам еден антички текст што одамна го имам прочитанорғ."
i. Cz: - "Kdepak, cituji starý text, který jsem si kdysi přečetl $l_{\mathrm{PF}}$.
j. Sn: - "Ne, navajam iz starega spisa, ki sem ga nekoč prebral ${ }_{\mathrm{PF}}$."

If we concentrate on the event of William's reading the ancient text, the important information is not the exact time at which he read the text or that he finished reading the text. What is important is merely the fact that he read the text. In other words: at some time in the extended now past, there existed an event of William reading a particular ancient text. (3) is thus a clear case of the existential type fake IPF. Of the languages where a translation is available, an existential type fake IPF is used in Uk, Bg, Pl, Hr and Sk in addition to $\mathrm{Ru}$. In Sr, Mk, Cz and Sn a PF VP is used.

Now recall the imperative clause in (1). A nurse is impressed by one of her patients, Korčagin, who does not complain even though he is severely injured. The nurse writes in her diary that now she understands why he does not groan. She has asked him, and he replied: Read the novel "The Gadfly", then you'll know.

Korčagin's message to the nurse is not that she must finish the reading of the novel and/or that she must do it immediately. What is important is simply that she reads it, at some time in the future. The parallel between the imperative clause in (1) and the declarative clause in (3) is evident.

Examples such as $(1 \mathrm{a}-\mathrm{h})$ strongly suggest that we find the existential type fake IPF in imperatives too. In both (1) and (3) the event time is included in a wide reference time (cf. Klein (1995)). The difference is just that in (3), the reference time is the extended past whereas in (1) it is the extended now future.

[6] The English translation is also from ParaSol. 
Thus, in (1) an existential type fake IPF is used in Ru, By, Uk, Bg, Sr, Hr, US and Sn. A PF VP is used in Pl, Mk, Sk and Cz.

[5] THE PRESUPPOSITIONAL TYPE FAKE IPF

\section{[5.1] Introduction}

In declaratives and interrogatives in the past tense, the most widespread type of the fake IPF is the existential type. In imperatives, however, the presuppositional type is, by far, the most frequent type. Recall (2) and consider (4) below, where the priest suspects four boys of having tobacco in their pockets.

(4) a. Ru: - "Вывернитерғ карманы! Ну, живо! Что я вам говорю? Выворачивайте IPF!" (ParaSol. Ostrovskij: KZS)

"Turn out your pockets! Come on, hurry up! Do you hear me? Turn [them] out!"7

b. Ву: - “Выверніцере кішэні! ... ВыварачвайцеІрғ!"

c. Uk: - "Вивернітьрғ кишені! ... Вивертайте IPF!"

d. Pl: - "Wywróćcie $e_{\mathrm{PF}}$ kieszenie! ... Wywracajcie ${ }_{\mathrm{IPF}} ! "$

e. Bg: - "Обърнете Рғ джобовете си! ... Обръщайте ІРF!"

f. Hr: - "Izvrnite $e_{\mathrm{PF}}$ džepove! ... Izvrćite $e_{\mathrm{IPF}}$, kad vam govorim!"8

In the declarative clauses in (2), an event of writing a love letter to Vera is referred to first by a PF VP and then again by an IPF VP. The writing event is old information - it is presupposed, anaphoric - in the second sentence. In the imperative clauses in (4), a turning-out-the-pockets event is described first by a PF VP. Then a turning-out-the-pockets event is referred to again, this time by an IPF VP. The similarities between (2) and (4) are obvious. However, whereas we can argue that PF napisal and IPF pisal in (2) do refer to one and the same event we cannot straightforwardly say the same about PF Vyvernite and IPF Vyvoračivajte in (4). For one, whereas napisal and pisal refer to a writing-event that did take place in the past, imperatives describe events that may or may not take place in the future. We do not know whether or not the events described will ever exist.

Before we can conclude that we do find the presuppositional type fake IPF in the imperative, two main problems must be resolved. First, there is the focus problem and second, the inaccessibility problem. I will discuss each of them briefly below. ${ }^{9}$

[7] The English translation of this example is due to Forsyth $(1970,208)$.

[8] The other translators resolve this case in different ways. In $\mathrm{Cz}$, for example, one PF infinitive is used twice, and in Sr one IPF imperative is used twice. In US a PF imperative is followed by an imperative of an IPF distributive Aktionsart verb.

[9] For an extensive discussion, see Alvestad (2013). 


\section{[5.2] The focus problem}

In the relevant declarative sequence in (2), there is a clear partition into presupposition - pisal - and focus - karandašom. Pisal karandašom brings new information into the context: the fact that the letter was written in pencil. In (4), on the other hand, there is no such clear partition. The imperative clause in question consists of only one word, the verb, so there is no other constituent to which the phonological focus can be shifted.

\section{[5.3] The inaccessibility problem}

In formal semantics, imperatives are often considered to be modal operators. This, according to widely held assumptions about the accessibility of antecedents - in Discourse Representation Theory (DRT) (Kamp \& Reyle 1993), for example makes the eventive discourse referent of PF Vyvernite inaccessible to the eventive discourse referent of IPF Vyvoračivajte.

Furthermore, modal operators are analyzed in terms of quantification over possible worlds. ${ }^{10}$ Since imperatives describe events in possible worlds, then if (4) were a direct parallel to (2), the two imperatives in (4) would have to refer to the exact same event(s) in the exact same world(s). Granted, in (4) the speaker is one and the same in both imperatives so we could perhaps argue that he has one and the same event token in mind. Often, however, the sentence containing the antecedent and the sentence containing the anaphor are uttered by two distinct speakers, as in (5) below.

(5) Ru: A: - Vyključ $\iota_{\text {PF }}$ svet! B: - Vyključaj IPF sam!

A: - Turn off the light! B: - Turn it off yourself!

The strong hypothesis of event identification, according to which the turn-off event(s) in A's wish worlds is/are identical to the turn-off event(s) in B's wish worlds, cannot be upheld.

\section{[5.4] Resolving the focus problem}

The information structural focus problem does in fact not only occur in the case of presuppositional type fake IPFs in imperative clauses. Consider B's reply in (6) below, from Mueller-Reichau (2011, ex. (1)).

(6) Ru: A: Konja poil $l_{\mathrm{IPF}}$ ? (horse ACC $_{\text {water }}$ IPF, PAST, M.SG.)

Did you water the horse?

B: Poil IPF. (water IPF, PAST, M.SG.)

Yes, I did [water [it]].

[10] Following Kaufmann (2012), I take imperatives to be necessity modals and, thus, analyze them in terms of universal quantification over possible worlds. 
B's utterance is a declarative sentence. IPF Poil 'watered' in this sentence is presuppositional. It refers to the event introduced in the context by IPF poil 'watered' in A's question. ${ }^{11}$

The phonological focus in B's sentence cannot be on any constituent other than the verb, yet the semantic content of the verb is known. However, B does bring some new information into the context: the fact that the proposition is true. What is focused in B's sentence is the truth of the proposition. Höhle (1992) refers to this type of focus as Verum focus.

When the phenomenon corresponding to Verum focus occurs in clause types other than declaratives, Höhle (1992) refers to it as the Illocution Type interpretation of Verum (op. cit.: 117). He argues that Verum is "(not a truth predicate but rather) [...] a variable over" illocution type operators (ibid.). When the lexical content of the verb is backgrounded, the illocution type operator becomes foregrounded. The effect is that the lexical content of the verb is, as it were, "presupposed to be known" (ibid.). What is focused in the imperative clause Vyvoračivajte is the mere speech act, which in this case is a speech act of ordering, or demanding.

The Macedonian translation of Ru IPF Vyvoračivajte serves to illustrate this point. Specifically, instead of using a presuppositional type fake IPF the Macedonian translator introduces a new PF imperative: Pobrzajte 'hurry up'.

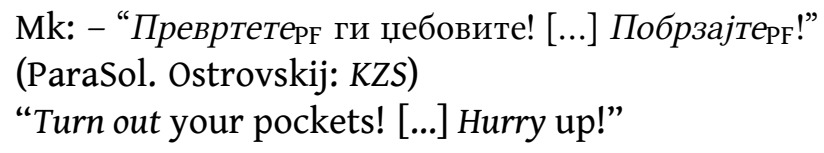

Thus, in the Macedonian translation it is spelled out: at the time of the utterance of PF Pobrzajte 'Hurry up' (for Ru IPF Vyvoračivajte), the lexical content of PF Prevrtete (for Ru PF Vyvernite 'Turn out') is indeed "presupposed to be known", in the words of Höhle $(1992,117)$.

Summing up, the phonological focus on the verb allows for an intriguing partition after all: it permits both a presupposition - Vyvoračivajte - and an information structural focus - Vyvoračivajte. ${ }^{12}$

[11] Without further context, IPF poil 'watered' in A's question may also be a presuppositional type fake IPF but with a covert antecedent. The VP then refers to a water-event which the interlocutors, at the time of A's utterance, have already discussed. In this case, A's question for B in (6) can be paraphrased as follows: Did you bring about the water-event (that we talked about)? (For a detailed discussion of covert antecedents in the case of imperatives, including how we can capture the phenomenon in a theoretical framework, see Alvestad (2013).)

[12] In my theoretical analysis, Speech Act focus is represented as a condition on event types. See Alvestad (2013, 244ff) for details. 


\section{[5.5] Resolving the inaccessibility problem}

We have seen that it may be hard to argue for event anaphora in the case of imperatives. A case in which event token identification is impossible is (8), where the two events of selling the chest are included in distinct reference times. Skavronov suggests that he and Klaša sell the chest while Roman is away, whereas Klaša suggests that Skavronov sell the chest when she is dead.

(8) Ru: - Давай, пока Романа нет, комод продадимрғ ... - Нет, сказала Клаша Скавронову. - Нет и нет. Как помру, продавайте $\mathrm{IPF}\left({ }^{*}\right.$ продайте жива, не дам (С. Антонов). (Khrakovskij 1988, 282, ех. (45))

"Come on, let's sell the chest while Roman's not here..." "No", Klaša said to Skavronov. "No, no, no. As soon as/When I'm dead, sell it. But while I'm alive, I won't give it away." (S. Antonov)

The inaccessibility problem can be solved, however, if we analyze such cases in terms of event type presuppositions. In DRT, discourse referents for event types can be freely declared at any level of a DRS (Discourse Representation Structure), particularly, "at a level where they are accessible for a presupposed event type referent coming from a presuppositional type fake IPF" (Alvestad 2013, 310). ${ }^{13}$

Event type identification does perhaps not tie the IPF imperative as tightly together with the discourse as event token identification does. It does, however, account for the strong intuition that the IPF is used because "the course of action described in the imperative has already been put under consideration in the discourse" (ibid.).

\section{[6] EXAMPLES ANALYSED IN TERMS OF EVENT TYPE PRESUPPOSITION}

The analysis in terms of event type identification captures the use of an IPF imperative VP in cases as diverse as (4), (5), and (8)-(15), and perhaps more. The discourse may be a monologue or a dialogue; the antecedent may be modal or non-modal; the sentence contributing the antecedent may be a declarative, an interrogative or an imperative clause; the subject of the imperative VP may be identical to the subject of the antecedent VP, or a subset thereof (as in (8) and (10)); the two events described may be included in distinct reference times; and the two VPs may belong to distinct aspectual pairs (as in (10) and (13)).

NON-MODAL ANTECEDENT IN DECLARATIVE. DIALOGUE

Ru: - Вы грубиян! - закричал Толстый. Вас гнать надо! Я на вас докладную подамРF - Ну и подавайте IPF, мрачно сказал Корнеев. - Займитесь любимым делом. (А. и Б. Стругацкие). (Khrakovskij 1988, 286, ex. (68))

[13] In DRT, predicates can be treated as constants of the form " $\mathrm{P}=$..." on a par with propositions, represented as "K = ..." (cf. Asher (1993, 225ff). See Alvestad (2013, 240ff) for details. 
"You boor!" Tolstyj shouted. "I'll have to drive you away! I'm going to report you!" "Go on. Report me!" Korneev said gloomily. "Do as you wish." (A. and B. Strugackij)

(10) NON-MODAL ANTECEDENT IN DECLARATIVE. MONOLOGUE

$\mathrm{Ru}$ : Теперь мы запишем $\mathrm{PF}$ это предложение. Пишите $\mathrm{IPF}_{1}$ !

(Schlegel 1972, 91)

Now we'll write this sentence. Write (it)!

(11) NECESSITy MOdAl ANTECEDENT IN DEClARATIVE. MONOLOGUE

Ru: - Алеша, ты забыл? Тебе нужно позвонитьрғ! Звонй

(Rassudova 1982, 133)

"Aleša, have you forgotten? You have to call! Call immediately!"

(12) MODAL ANTECEDENT want IN DECLARATIVE. DIALOGUE

Pl: A: - Chciałbym pooglądać PF program telewizyjny.

B: - A ogladaj IPF (sobie). Mnie jest wszystko jedno.

A: - I would like to watch a program on the TV.

B: - Well, watch it. I don't care. (Bogusławski 2011, 147, ex. (29)).

(13) MODAL ANTECEDENT want IN DECLARATIVE. MONOLOGUE

$\mathrm{Ru}:$...И говорит: “Это, наверно, сазан. На, говорит, держи удочку, я хочу, чтобы ты вытащилрғ." Я как взял, насилу удержал. А папа говорит: “Ты сильно не дергай, оборвеш леску, а дай ему поводить, он устанет, тогда ты его и вытягивай

... And he said 'That must be a carp. Here, you hold the rod, I want you to land it.' When I took the rod I could scarcely hold it, but Dad said 'Don't tug hard or you'll break the line. Let it play about a bit. It will get tired, and then you can pull it out.' (Forsyth 1970, 199)

(14) POSSIBILITY MODAL ANTECEDENT IN INTERROGATIVE. DIALOGUE

$\mathrm{Ru}: \mathrm{A}:-$ Можно войтиРР?

A: - May I come in?

B: - Входите IPF! (Šatunovskij 2009, 263)

B: - Come in!

(15) MODAL ANTECEDENT want IN INTERROGATIVE

Uk: - “Тоню, хочеш, я розповімер тобі про Христинку?” - “РозповідайІРF," - жваво сказала Тоня. (ParaSol. Ostrovskij: KZS)

"Tonja, do you want me to tell you about Khrystynka?" "Tell me," Tonja urged him.

[7] CONCLUDING REMARKS AND FURTHER OUTLOOK

This paper is based on a comparative study of aspect use in Slavic imperatives. The study corroborates the observation made by, inter alia, Dickey (2000), Benac- 
chio (2010), and von Waldenfels (2012) of a cross-Slavic variation in aspect use, specifically, that in West-Slavic, PF is most frequent, whereas in East-Slavic, IPF is most frequent. The study also corroborates the observation made by Benacchio (2010) and von Waldenfels (2012) that in the imperative, IPF is remarkably widely used, particularly in the East-Slavic languages, to refer to single, complete events.

Contrary to aspectologists who argue that the aspects take on distinct meanings in the imperative - such as Padučeva (1996) and others, according to whom IPF in the imperative includes the semantic component 'immediately' and focuses the attention on the initial phase of the event; Lehmann (1989), who argues that the aspects are associated with distinct sets of speech act types, where IPF is associated with, inter alia, permissions; and Benacchio (2010), who argues that IPF designates a particularly high or particularly low degree of politeness - I proposed a simpler solution. Specifically, I argued that what we see when IPF is used to refer to complete events in the imperative is in fact the same phenomenon that is called the general-factual IPF when it occurs in the indicative. On this analysis, any connection between a given aspect, on the one hand, and which part of the event is in focus, a certain speech act type, or degree of politeness, on the other, is indirect and an epiphenomenon of aspect use.

Since the term 'general-factual' is inappropriate in imperatives, I used the term 'fake' IPF instead. Grønn (2004) identifies two types of the fake IPF in declaratives and interrogatives: the existential type and the presuppositional type. Based on examples from the ParaSol corpus and the aspect literature I have shown that we find both types in imperatives too, the presuppositional being the most frequent.

As regards the presuppositional type, I set out with a strong hypothesis of event token identification. It became evident, however, that some IPF imperatives are not amenable to such an analysis. I then proposed an analysis in terms of event type presupposition. Event type identification may not tie the IPF imperative as tightly together with the discourse as event token identification does, but it does capture the intuition that an IPF imperative is used because the course of action described has already been introduced in the context.

Consequently, there might be reason to revisit the hypothesis of Grønn (2004) that the presuppositional type fake IPF invariably involves event token anaphora.

A question that was not raised in this paper was why the individual Slavic languages resolve cases of aspectual competition differently. To establish the exact rules, pragmatic or other, that govern the use of fake IPF versus PF in such cases, further research is needed. 


\section{ACKNOWLEDGEMENTS}

Thanks are due to Arnim von Stechow and Kjell Johan Sæbø for discussing some of the topics of this paper with me. Thanks are also due to the anonymous reviewer, who contributed to significant improvements of the paper.

\section{REF ERENCES}

Alvestad, Silje Susanne. 2013. Beware of fakes! Fake imperfectives in the Slavic imperative. University of Oslo: PhD Thesis.

Asher, Nicholas. 1993. Reference to abstract objects in discourse. Dordrecht: Kluwer Academic Publishers.

Benacchio, Rosanna. 2010. Vid i kategorija vežlivosti v slavjanskom imperative: sravnitel'nyj analiz. Munich and Berlin: Kubon und Sagner.

Bogusławski, Andrzej. 2011. Thinking one's wishes and acting according to one's wishes. The imperative and related tools revisited. In A. Brożek, J. Jadacki \& B. Žarnić (eds.), Theory of imperatives from different points of view, 137-147. Warsaw: Wydawnictwo Naukowe Semper.

Dickey, Stephen M. 2000. Parameters of Slavic aspect. Stanford, California: CSLI.

Forsyth, John. 1970. A grammar of aspect. Cambridge, UK: Cambridge University Press.

Fortuin, Egbert \& Heleen Pluimgraaff. forthcoming. Aspect of the imperative in Slovene as compared to Russian.

Grønn, Atle. 2004. The Semantics and Pragmatics of the Russian Factual Imperfective. University of Oslo: Doctor Artium Thesis.

Grønn, Atle. 2013. Aspect and tense in counterfactual main clauses: Fake or real? In F. Josephson \& I. Söhrman (eds.), Diachronic and typological perspectives on verbs, 133-158. John Benjamins Publishing Company.

Höhle, Tilman N. 1992. Über Verum-fokus im Deutschen. In J. Jacobs (ed.), Informationsstruktur und Grammatik, 112-141. Westdeutscher Verlag.

Iatridou, Sabine. 2000. The grammatical ingredients of counterfactuality. Linguistic Inquiry 31(2). 231-270.

Iatridou, Sabine. 2009. About the imperfective in counterfactuals. Paper presented at Yale Imperfective Workshop. http://web.mit.edu/linguistics/ people/faculty/iatridou/imperfective_counterfactual.pdf. 
Kamp, Hans \& Uwe Reyle. 1993. From discourse to logic: Introduction to modeltheoretic semantics of natural language, formal logic and Discourse Representation Theory. Dordrecht: Kluwer.

Kaufmann, Magdalena. 2012. Interpreting imperatives. Springer.

Khrakovskij, V. S. 1988. Imperativnye formy NSV i SV v russkom jazyke i ikh upotreblenie. Russian linguistics 3(12). 269-292.

Klein, Wolfgang. 1995. A time-relational analysis of Russian aspect. Language 71(4). 669-95.

Lehmann, Volkmar. 1989. Pragmatic functions of aspects and their cognitive motivation. russian aspects in the context of the imperative and the infinitive. In L. G. Larsson (ed.), Proceedings of the second Scandinavian symposium on aspectology, 77-88. Uppsala.

Mueller-Reichau, Olav. 2011. Why kratnost'? On Russian Factual Imperfective. In U. Junghanns, D. Fehrmann, D. Lenertová \& H. Pitsch (eds.), Formal Description of Slavic Languages: Proceedings of FDSL 9, vol. 28 Linguistik International, Göttingen: Peter Lang.

Padučeva, Elena. 1996. Semantika vremeni i vida v russkom jazyke. Moscow: Jazyki russkoj kul'tury.

Prokofeva, R. 1959. How the steel was tempered. Moscow: Izdatel'stvo literatury na inostrannykh jazykakh/Foreign languages publishing house. Translation of Nikolaj Ostrovskij's Kak zakaljalas' stal' (1936).

Rassudova, Ol'ga. 1982. Upotreblenie vidov glagola $v$ sovremennom russkom jazyke. Moscow: Izdatel'stvo russkij jazyk.

Schlegel, Hans. 1972. Der Gebrauch des russischen Verbalaspekts, vol. II. Potsdam.

Vendler, Zeno. 1957. Verbs and times. Philosophical Review 46. 143-160.

Šatunovskij, I. B. 2009. Problemy russkogo vida. Moscow: Jazyki slavjanskikh kul'tur.

von Waldenfels, Ruprecht. 2012. Aspect in the imperative across Slavic - a corpus driven pilot study. Oslo Studies in Language 4(1). 141-154. 
AUTHOR CONTACT INFORMATION

Silje Susanne Alvestad

Department of Literature, Area Studies and European Languages

University of Oslo

Norway

s.s.alvestad@ilos.uio.no 